\title{
$\mathrm{M}|\mathrm{R}| \mathrm{S}$
}

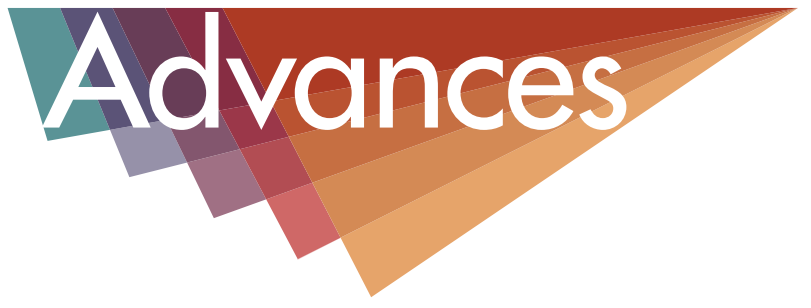

\section{Energy and Sustainability}




\section{MRS Advances: Energy and Sustainability}

Associate Editor: David F. Bahr, Purdue University

Principal Editor: Stephen J. Harris, Lawrence Berkeley National Lab

Principal Editor: Yat Li, University of California-Santa Cruz

Principal Editor: Lan Fu, Australian National University

Principal Editor: Jia Zhu, Nanjing University

Principal Editor: De-en Jiang, University of California-Riverside

Principal Editor: Martin Kuball, University of Bristol

Principal Editor: David S. Ginley, National Renewable Energy Lab

\section{MRS Advances Editorial Board:}

Chair: David F. Bahr, Purdue University

Asa H. Barber, University of Portsmouth

Frank W. DelRio, National Institute of Standards and Technology

Elizabeth L. Fleischer, Materials Research Society

Marilyn L. Minus, Northeastern University

Roger J. Narayan, University of North Carolina/North Carolina State University

\section{MRS Editorial Office:}

Ellen W. Kracht, Publications Manager, Materials Research Society, Warrendale, PA

Susan Dittrich, Journals Editorial Assistant, Materials Research Society, Warrendale, PA

Kirby L. Morris, Journals Production Assistant, Materials Research Society, Warrendale, PA

Eileen M. Kiley, Director of Communications, Materials Research Society, Warrendale, PA

MRS Advances (EISSN: 2059-8521) is published by Cambridge University Press, 32 Avenue of the Americas, New York, NY 10013-2473 for the Materials Research Society.

Copyright (C) 2016, Materials Research Society. All rights reserved. No part of this publication may be reproduced, in any form or by any means, electronic, photocopying, or otherwise, without permission in writing from Cambridge University Press. Policies, request forms and contacts are available at: http://www.cambridge.org/rights/permissions/ permission.htm. Permission to copy (for users in the USA) is available from Copyright Clearance Center at: http://www.copyright.com, email: info@copyright.com.

\section{Purchasing Options:}

Premium Subscription- Premium Subscription includes current subscription and one year's lease access to the full MRS Online Proceedings Library Archive for \$6,875.00 / £4,655.00 / €6,330.00. Subscription-Subscription with perpetual access to the content subscribed to in a given year, including three years of back-file lease access to content from the MRS Online Proceedings Library Archive. The price for a 2016 subscription is $\$ 2,875.00 / £ 1,855.00 / € 2,500.00$. MRS Members- Access to MRS Advances is available to all MRS members without charge.

\section{Contact Details:}

For all inquiries about pricing and access to MRS Advances, please get in touch via the following email addresses: online@cambridge.org (for the Americas); library.sales@cambridge.org (for UK, Europe, and rest of world).

\section{journals.cambridge.org/adv}




\section{CONTENTS}

* Thin n/p GaAs Junctions for Novel High-efficiency Phototransducers

Based on a Vertical Epitaxial Heterostructure Architecture . . . . . . . .881

M.C.A. York, F. Proulx, D.P. Masson,

A. Jaouad, B. Bouzazi, R. Arès, V. Aimez, and S. Fafard

* Impact of Layer Number on Flexible High-voltage Nanostructured

Solar Cells. . . . . . . . . . . . . . . . . . . . 891

Roger E. Welser, Ashok K. Sood,

S. Rao Tatavarti, Andree Wibowo, and David M. Wilt

Optical Approaches to Improving Perovskite/Si Tandem Cells . . . . . . 901

Haejun Chung, Xingshu Sun, and Peter Bermel

Investigation of the Influence of Deep-level Defects on the Conversion

Efficiency of Si-based Solar Cells. . . . . . . . . . . . . 911

Vladimir G. Litvinov, Nikolay V. Vishnyakov,

Valery V. Gudzev, Nikolay B. Rybin,

Dmitry S. Kusakin, Alexander V. Ermachikhin,

Sergey M. Karabanov, Sergey P. Vikhrov,

Andrey S. Karabanov, and Evgeny V. Slivkin

High Rate Deposition of Thin Film CdTe Solar Cells by Pulsed dc

Magnetron Sputtering . . . . . . . . . . . . . . 917

P.M. Kaminski, A. Abbas, S. Yilmaz,

J.W. Bowers, and J.M. Walls

Degradation of Co-evaporated Perovskite Thin Films . . . . . . . 923

Congcong Wang, Youzhen Li, Xuemei Xu,

Benjamin Ecker, Chenggong Wang,

and Yongli Gao

Polymer Solar Cells for Indoor Energy Harvesting ～. . . . . . . . 931

Yoichi Aoki

Electronic Properties of CdTe/CdS Solar Cells as Influenced by a

Buffer Layer . . . . . . . . . . . . . . . . . . . . . 937

Y.G. Fedorenko, J.D. Major,

A. Pressman, L. Phillips, and K. Durose

*Invited Paper 
Oxidation of Planar and Plasmonic Ag Surfaces by Exposure to

$\mathrm{O}_{2} /$ Ar Plasma for Organic Optoelectronic Applications . . . . . . . 943

Christopher E. Petoukhoff, Catherine Antonick,

M. Bala Murali Krishna, Keshav M. Dani, and Deirdre M. O'Carroll

Experimental Demonstration of a Dispersive Spectral Splitting

Concentrator for High Efficiency Photovoltaics . . . . . . . . . . 949

Carlo Maragliano, Matteo Chiesa, and Marco Stefancich

Comparison of Anti-reflective Properties of Single Layer Anatase and Rutile $\mathrm{TiO}_{2}$ on GaAs Based Solar Cells . . . . . . . . . . 957

R. Vasan, Y.F. Makableh, and M.O. Manasreh

Screen Printable Semiconductor Grade Inks for $\mathbf{N}$ and $P$ Type

Doping of Polysilicon. . . . . . . . . . . . . . . . 965

Aditi Chandra, Mao Takashima,

Martha Montague, Joey Li, and Arvind Kamath

Visible Light Photodiodes and Photovoltages from Detonation

Nanodiamonds . . . . . . . . . . . . . . . . 971

Bohuslav Rezek, Stepan Stehlik,

Alexander Kromka, Jean-Charles Arnault,

Martin Weis, and Jan Jakabovic

$\mathrm{MoO}_{\mathrm{x}}$ Hole Collection Layer for a-Si:H Based Photovoltaic Cells. . . . 977 Erenn Ore, Jimmy Melskens, Arno Smets, Miro Zeman, and Gehan Amaratunga

Substrate Geometry CdTe Solar Cells with Catalytically-grown Nano-rough Surfaces. . . . . . . . . . . . . . . 985 G. Papageorgiou, J.D. Major, and K. Durose

Dye Sensitized Solar Modules with Embedded Silver Lines . . . . . . 991 Kerem Cagatay Icli and Macit Ozenbas 